\title{
Criminal Responsibility towards Criminals of Abortion in Indonesia
}

\section{Zahri Aeniwati*) and Sri Kusriyah**)}

*Student of Master of Law, Faculty of Law, Universitas Islam Sultan Agung Semarang, E-mail: zahriaeniwati@gmail.com

**)Faculty of Law, Universitas Islam Sultan Agung Semarang

\begin{abstract}
.
This study aims to determine and describe the criminal liability of perpetrators of abortion in Indonesia. This research is a doctrinal legal research, which is descriptive analysis. The data used is secondary data obtained through library research, which is then analyzed qualitatively. The results of this research show that criminal liability for perpetrators of abortion in Indonesia based on the Criminal Code is regulated in Book Two of Chapter XIV on Crimes of Decency, especially Article 299, and Chapter XIX Articles 346-Articles 349 which are classified as crimes against life. The prohibition on abortion in the Criminal Code is contained in Article 299, Article 346, Article 347, Article 348, and Article 349, which clearly regulates the prohibition of having an abortion for any reason, including abortion for emergency reasons (forced). The provisions for regulating abortion in Act No 36 of 2009 are set forth in Article 75, Article 76, Article 77, and Article 194. Even though, the law prohibits the practice of abortion, in certain circumstances there is a possibility. Abortion practices that are contrary to statutory regulations are regulated in Article 194 of Act No 36 of 2009, with a maximum imprisonment of 10 years and a maximum fine of IDR 1,000,000,000.00 (one billion rupiah).

Keywords: Accountability; Criminal Law; Crime; Abortion.
\end{abstract}

\section{Introduction}

Continuing offspring is one of the goals of marriage. Children will provide joy in the household, and parents really hope that when they get older, children will be able to care for them and care for them as parents have treated since they were young. Nobody does not want children in their life, of course, for those who are married.

Every couple, would want the presence of a child. As human instinct when born as a person of the opposite sex (as male and female) always brings with it sexual instinct. Sexual instincts which are built from the relationship between two persons of opposite sex will give rise to a process known as reproduction. ${ }^{1}$

The couple will make various ways and efforts to get offspring (children), such as IVF or other efforts. Couples are willing to pay a lot of money to get a child who is a gift from Allah SWT. It's just that, not everyone wants the presence of a child, there are even people who try to kill the life of the child or the fetus in the womb, which is known as abortion.

\footnotetext{
1 Seran, Marcel and Anna Maria Wahyu Setyowati. (2010). Dilema Etika dan Hukum Dalam Pelayanan Medis. Cetakan Kesatu. Bandung: Mandar Maju. p. 57.
} 
Another popular term for abortion is abortion. From a legal point of view, abortion is not exactly the same as the practice of abortion, because from a legal point of view (criminal) in the practice of abortion there are 2 (two) forms of action, namely: ${ }^{2}$

- The act of aborting the womb (afdrijven);

- The deadly deeds (dood'doen) of the womb.

The Big Indonesian Dictionary states that abortion comes from the word "abortion", which is translated as abortion. According to the Big Indonesian Dictionary, the meaning of abortion is: the scattered embryo that is no longer possible to live (before the end of the fourth month of pregnancy); miscarriage; miscarriage; cessation of normal growth (about living things) and shedding (fetuses). ${ }^{3}$

According to Eastman, abortion is a state of termination of a pregnancy in which the fetus is not able to stand alone outside the uterus. It cannot be interpreted if the fetus weighs between 400-1000 grams or a pregnancy of less than 28 weeks. ${ }^{4}$

The practice of abortion is increasingly occurring in society, especially by girls because they are pregnant outside of marriage. Free association makes children do such actions. Unwanted Pregnancy (KTD) that ends with unsafe abortion is just one of the cases that have occurred in Indonesia. The Center for Health Research at the University of Indonesia found that an average of 2 million cases of unsafe abortion occur annually. ${ }^{5}$

Babies who are the result of extramarital relations are highly unwelcome by the couple, and they also try to abort the fetus because they are afraid of having children outside of marriage, are not ready to have children, or the shame they must bear because they are pregnant outside of marriage. Whatever their reasons, aborting the fetus or having an abortion of an unborn baby is a grave sin and is an act against the law (a crime).

This act of abortion is supported by the existence of illegal abortion clinics and the sale of abortion drugs that can be found online. As is the case with abortion practices that occurred in a clinic in Senen, Central Jakarta. The clinic is known to have aborted tens of thousands of fetuses since its establishment in 2002. The perpetrator offers to practice abortion through the official klinikaborsi.com website. For their actions, the perpetrators can be subject to criminal charges based on the Criminal Code (KUHP) and Act No 36 Of 2009 concerning Health.

In general, every country has laws prohibiting abortion or abortion. However, this is not absolute. Abortion provocatus can be justified as a treatment, if it is the only way to save the mother's soul from the threat of death abortion

\footnotetext{
2 Yunanto, Ari and Helmi. (2010). Hukum Pidana Malpraktik Medik, Tinjauan dan Perspektif Medikolegal. Edisi Pertama. Yogyakarta: ANDI. p. 59.

3 Asmarawati, Tina. (2013). Hukum \& Abortus. Edisi Pertama. Cetakan Kesatu. Yogyakarta: Deepublish. p. 5 and 6.

4 Fauziyah, Yulia and Cecep Triwibowo. (2013). Medical Book, Bioteknologi Kesehatan Dalam Perspektif Etika dan Hukum. Cetakan Pertama. Yogyakarta: Nuha Medika. p. 144.

5 Damayanti, Eka and Aryani Witasari, December 2019. Legal Protection from Provocate Abortion Againts the Child Conceived Because Rape (Case Study on Jurisdiction Ex Residency of Cirebon). Jurnal Daulat Hukum. Vol. 2 No. 4, Faculty of Law, Universitas Islam Sultan Agung, Semarang. p. 602.
} 
provocatus therapeuticus). This medical indication can change according to the development of medical science, because of the influence of the times there are several kinds of diseases that are no longer affecting maternal safety, among others, tuberculosis, hypertension, and so on. ${ }^{6}$

An abortion if performed by a doctor, and not in accordance with medical indications, apart from violating KODEKI, can also be classified as a violation of medical discipline, as stated in the Regulation of the Indonesian Medical Council (KKI) Number 4 of 2011 point 11, namely: aims to terminate a pregnancy that is not in accordance with the provisions of the applicable legislation, where the sanctions given to doctors who violate discipline will be given verbal and written warnings, revocation of registration certificates (STR) or license to practice (SIP). ), and must re-attend education or training in medical education institutions. ${ }^{7} \mathrm{~A}$ professional carrier, regardless of the type of profession, should have a professional attitude in carrying out that profession. Likewise a doctor. ${ }^{8}$

In some cases of abortion practice, the perpetrator is not a doctor who has the competence and expertise in the medical field, especially the womb. Lyle Spencer \& Signe Spencer stated that competence is a basic characteristic of individual behavior related to the criteria for effective reference and or superior performance in a job or situation. ${ }^{9}$

People who are not competent in carrying out their duties and jobs will be able to harm other parties. Likewise with the practice of abortion which is carried out by people who are not experts and are not due to medical indications, it can be subject to criminal liability. Responsibility is the willingness or ability to accept and bear all the legal consequences of all actions and the consequences of actions that have been taken, thus responsibility arises from the time the action begins until the action is completed. ${ }^{10}$

In general, society recognizes law as a rule, norm, code of conduct or statutory regulations which, if violated, will be subject to sanctions. ${ }^{11}$ The purpose of establishing law is as an order that must be implemented by the community, so as to create a safe, serene and peaceful environment, apart from realizing truth and justice. Grotius stated that: "Law is a rule of moral action obliging to that which is right" (law is a rule of moral action that will lead to what is right), ${ }^{12}$ then Esmi

\footnotetext{
${ }^{6}$ Asmarawati, Tina. op.cit. p. 2.

${ }^{7}$ Handayani, Trini and Aji Mulyana. (2019). Tindak Pidana Aborsi. Cetakan Pertama. Jakarta: Index. p. 16.

8 Yunanto, Ari and Helmi. (2010). Hukum Pidana Malpraktik Medik, Tinjauan dan Perspektif Medikolegal. Edisi Pertama. Yogyakarta: Andi. p. 10.

9 Sudarmanto. (2018). Kinerja dan Pengembangan Kompetensi SDM, Teori, Dimensi Pengukuran, dan Implementasi Dalam Organisasi. Cetakan Keempat. Yogyakarta: Pustaka Pelajar. p. 46-49.

10 Maskawati, Andriani Misdar, and Muji Iswanty. (2018). Hukum Kesehatan, Dimensi Etis dan Yuridis Tanggung Jawab Pelayanan Kesehatan. Yogyakarta: Litera. p. 37.

11 Arsyad, Jawade Hafidz and Dian Karisma. (2018). Sentralisasi Birokrasi Pengadaan Barang \& Jasa Pemerintah. Cetakan Pertama. Jakarta: Sinar Grafika. p. 63.

12 Praja, Juhaya S. (2011). Teori Hukum dan Aplikasinya. Cetakan Pertama. Bandung: Pustaka Setia. p. 169.
} 
Warassih stated that in essence law contains abstract ideas or concepts. Even though it is abstract, it is made to be implemented in everyday social life. ${ }^{13}$

The characteristic of law is to force accompanied by threats and sanctions, but the law is not forced to justify wrong issues, or force those who are not domiciled and have no bear. In order for the rules of social life to be really obeyed and obeyed so that they become the rule of law, then these social regulations must be equipped with an element of force. Law has the nature of regulating and forcing everyone to obey the order in society and to provide strict sanctions (in the form of punishment) for anyone who does not want to obey it. ${ }^{14}$

Doctors as professionals are responsible for every medical action performed on patients. In carrying out their professional duties, they are based on good intentions, namely making serious efforts based on their knowledge which is based on the doctor's oath, medical code of ethics, and professional standards to cure / help patients. ${ }^{15}$

Likewise, doctors who practice abortion without any medical indication must be legally responsible for their actions, because their actions have killed someone's life even though they are still in the form of a fetus, and this is prohibited by law. This study aims to identify and describe the criminal liability for abortion in Indonesia.

\section{Research methods}

The type of research used in writing this legal journal is doctrinal legal research. Doctrinal legal research is literature-based research whose focus is the analysis of primary and secondary legal materials ${ }^{16}$ which in this case relates to criminal liability for perpetrators of the crime of abortion in Indonesia. This research is descriptive analysis, because the researcher wishes to describe or explain the subject and object of the research, which then analyzes and finally draws conclusions from the results of the study. ${ }^{17}$ The data used in this research is secondary data. Secondary data is data obtained from library materials through library research, and this data is also obtained from agencies/institutions related to the purpose of this research. ${ }^{18}$ According to the data obtained during the research by reading library books, then analyzed. The analysis used in this research is qualitative data analysis.

\section{Results and Discussion}

13 Warassih, Esmi. (2010). Pranata Hukum, Sebuah Telaah Sosiologis. Cetakan Kedua. Semarang: Badan Penerbit Universitas Diponegoro. p. 68.

14 Suharto and Junaidi Efendi. (2010). Panduan Praktis Bila Menghadapi Perkara Pidana, Mulai Proses Penyelidikan Sampai Persidangan. Jakarta: Prestasi Pustaka. p. 25 and 26.

15 Sadi Is, Muhamad. (2017). Etika Hukum Kesehatan, Teori dan Aplikasinya Di Indonesia, Cetakan Kedua. Jakarta: Kencana Prenada Media. p. 101.

16 Susanti, Dyah Ochtorina and A'an Efendi. (2018). Penelitian Hukum (Legal Research). Jakarta: Sinar Garfika. p. 11.

17 Fajar ND, Mukti and Yulianto Achmad. (2010). Dualisme Penelitian Hukum Normatif dan Empiris. Yogyakarta: Pustaka Pelajar. p. 183.

18 Soeratno and Lincolin Arsyad. (2003). Metodologi Penelitian Untuk Ekonomi Dan Bisnis. Yogyakarta: UPP AMP YKPN. p. 173. 
Life is a gift given by Allah the Creator which must be respected by all people. The life that is given to every human being is a basic right that can only be revoked by the Creator. The right to life is one of the human rights listed in Article 28A of the 1945 Constitution of the Republic of Indonesia, which reads: "Everyone has the right to live and has the right to defend his life and life". With this right to life, the state will safeguard and protect the right to life of every citizen, so that the state through state law enforcers will act if there is and it is known that the right to life has been lost. 19

The deprivation of the right to life is punishable by criminal penalties, such as premeditated murder, negligence that causes the death of another person, and maltreatment that causes the death of another person. In addition, there are also criminal threats for the murder of newborns, including babies that are still in the womb (abortion). ${ }^{20}$

Abortion has been known since the beginning of human history and is believed to be the oldest method of preventing unwanted births, and until now is the most dangerous way because it often causes maternal death. If a woman is having a pregnancy without wanting it, and she cannot accept that state as her fate, then it is likely that she will make all kinds of efforts to abort the pregnancy. From ancient times there were traditional ways to abort, such as drinking herbal medicine, doing massage, putting all kinds of objects in the womb and so on, although in these ways women have to face the risk of losing their lives. ${ }^{21}$

Abortion or commonly referred to as abortion, entered human civilization because women did not want the pregnancy. Abortion is basically a phenomenon that lives in Indonesian society. ${ }^{22}$ As is the case with the discovery of an illegal abortion clinic in Central Jakarta, it shows that there are many cases of unwanted pregnancy.

Abortion is the premature discharge or discharge of the product of conception from a mother's womb. Abortion or abortion can occur spontaneously and artificial abortion. Spontaneous abortion is a natural mechanism for the release of an abnormal conception (miscarriage), while artificial abortion, also known as termination of pregnancy, has 2 (two) types, namely: ${ }^{23}$

- legal;

Legal abortion is performed by competent health or medical personnel based on medical indications, and with the consent of the pregnant mother and / or husband. Legal abortion is often called artificial abortion or abortion with medical indications. However, not every abortion that has medical indications can be artificial abortion. Other requirements that must be met by an abortion are:

\footnotetext{
${ }^{19}$ Muchtar, Masrudi. (2015). Bidan dan Dinamika Hukum Kesehatan Reproduksi di Indonesia. Cetakan Kedua. Sleman: Aswaja. p. 81.

20 Ibid. p. 81-82.

21 Soge, Paulinus. (2015). Hukum Aborsi Tinjauan Politik Hukum Pidana Terhadap Perkembangan Hukum Aborsi di Indonesia. Cetakan Ketiga. Yogyakarta: Universitas Atma Jaya Yogyakarta. p. 17.

22 Martha, Aroma Elmina and Singgih Sulaksana. (2019). Legalisasi Aborsi. Cetakan Pertama. Yogyakarta: UII Press. p. 4.

${ }^{23}$ Notoatmodjo, Soekidjo. (2010). Etika \& Hukum Kesehatan. Cetakan Pertama. Jakarta: Rineka Cipta. p. 135 and 136.
} 
- Abortion is only performed as a therapeutic measure;

- Approved in writing by two competent doctors;

- Conducted at a health care facility recognized by a legal authority.

- Illegal

Illegal abortion is performed by incompetent health or medical personnel, through non-medical means (massage, herbal medicine or ingredients), with or without the consent of the pregnant woman and / or her husband. Illegal abortions are often performed by qualified medical personnel, but have no medical indication.

Regulations regarding abortion are contained in the Criminal Code, which applies as general criminal law (lex generale), and also in Act No 36 of 2009 which replaces Act No 23 of 1992, and applies as a special criminal law (lex speciale). With the passing of Act No 36 Of 2009 which replaced Act No 23 Year 1992, the issue of abortion has gained legitimacy and affirmation.

In the Criminal Code, the act of deliberate abortion (abortion provocatus) is regulated in Book Two of Chapter XIV on Crimes of Decency, in particular Article 299, and Chapter XIX, Articles 346 to 349, and classified as crimes against life.

According to the juridical construction of laws and regulations in Indonesia, which are contained in Article 346-Article 349 of the Criminal Code, abortion is an act of aborting or terminating the womb by a woman or a person who is ordered to do so. A woman in this case is a pregnant woman who wants to abort her womb, while the actions that according to the Criminal Code can be ordered to do for that are a doctor, midwife or medic. ${ }^{24}$

The prohibition against abortion in the KUHP is contained in Article 299, Article 346, Article 347, Article 348, and Article 349 of the Criminal Code. These articles clearly and firmly regulate the prohibition of having an abortion for any reason, including abortion for reasons of emergency (forced), namely as a result of rape, both prohibiting the perpetrator and those who assist in having an abortion. Even medical professionals will get double the penalty for helping to have an abortion.

The Criminal Code recognizes the act of abortion provocatus criminalis, namely abortion that has a criminal nature, and does not recognize the act of abortion provocatus terapheuticus, which is an abortion that has no criminal character. The provisions in the articles of the Criminal Code clearly do not allow an abortion to be performed, if the provisions of the article are carried out absolutely and there is no acceptable reason whatsoever. All forms of abortion are prohibited for women, without providing an alternative to provide safe reproductive health technologies that can reduce the risk of death of a pregnant woman. The risk of death can be caused by the risk of serious diseases that endanger the life of the pregnant woman. Consequently, medical personnel, especially doctors, midwives. ${ }^{25}$

Explicitly, in Act No 36 of 2009, there are articles that regulate abortion, although in medical practice it contains various reactions and causes controversy in various levels of society. Although, the law prohibits the practice of abortion, in

\footnotetext{
${ }^{24}$ Handayani, Trini and Aji Mulyana. op.cit. p. 76.

25 Ibid. p. 86.
} 
certain circumstances it is permissible. The provisions for regulating abortion in Act No 36 of 2009 are set out in Article 75, Article 76, Article 77, and Article 194.

In Act No 36 of 2009, the prohibition on abortion is also regulated in Article 75 paragraph (1). Act No 36 Of 2009 states that:

- Everyone is prohibited from having an abortion;

- The prohibition as referred to in paragraph (1) can be exempted based on:

- An indication of a medical emergency detected from an early age in pregnancy, whether threatening the life of the mother and / or fetus, suffering from serious genetic diseases and / or congenital defects, or which cannot be repaired so that it makes it difficult for the baby to live outside the womb; or

- Pregnancy due to rape that can cause psychological trauma for the victim of rape.

- The action as referred to in paragraph (2) can only be carried out after going through pre-action counseling and / or advice and ended with post-action counseling carried out by a competent and authorized counselor;

- Further provisions regarding indications of medical emergencies and rape as referred to in paragraph (2) and paragraph (3) shall be regulated in a Government Regulation.

The exceptions are described in Article 75 paragraph (2), which is given only in 2 (two) of the following conditions:

- An indication of a medical emergency detected from an early age in pregnancy, whether threatening the life of the mother and / or fetus, suffering from serious genetic diseases and / or congenital defects, or which cannot be repaired so that it makes it difficult for the baby to live outside the womb; or

- Rape pregnancy which can cause psycho-logical trauma to the rape victim.

The act of abortion as regulated in Article 75 paragraph (2) of Act No 36 of 2009 can only be carried out after going through pre-action counseling and / or advice and ends with post-action counseling carried out by a competent and authorized counselor, which is described in Article 75 paragraph (3) of Act No 36 of 2009.

Looking at the formulation of Article 75 of Act No 36 of 2009, it appears that this Law clearly prohibits abortion, except for the type of abortion provocatus terapheuticus (abortion which is performed to save the life of the mother and / or her fetus). In the world of medicine, abortion provocatus medicalis can be performed if the life of the mother is in danger of death from the birth of an untimely baby or the condition of the mother who is pregnant before giving birth. Abortion can be performed if the child is thought to have severe defects and it is indicated that they cannot live outside the womb, for example the fetus has an ectopia cordalis disorder (the fetus will be born without a chest wall so that the heart can be seen), rickets (the fetus will be born with an open spine without being covered in skin), and anencephalus (the fetus will be born without a large brain). In Act No. 36 of 2009, it has also been stipulated that abortions performed by victims of rape are indicated to cause psychological trauma for the mother. ${ }^{26}$

${ }^{26}$ Ibid. p. 102. 
The law recognizes that everyone has reproductive rights, as regulated in Article 72 of Act No 36 of 2009, which states that:

Everyone has the right:

- Live a reproductive life and sexual life that is healthy, safe, and free from coercion and / or violence with a legal partner;

- Determine their reproductive life and free from discrimination, coercion, and / or violence that respects noble values that do not degrading human dignity in accordance with religious norms;

- Determine for yourself when and how often to reproduce medically healthy and not against religious norms;

- Obtain information, education, and counseling regarding correct and accountable reproductive health.

However, in the Ministerial Regulation Number 290 of 2008 concerning Medical Approval Measures and Act No 29 of 2004 concerning Medical Practice, there is not the slightest stipulation regarding the sanction for doctors who carry out abortion (abortion) on medical indications without the consent of the pregnant mother or his family.

The practice of abortion that is against the laws and regulations is illegal abortion. Criminal sanctions for perpetrators of illegal abortion are regulated in Article 194 Act No 36 of 2009. Article 194 of Act No 36 Of 2009 can ensnare doctors and / or health workers who deliberately carry out illegal abortions as well as women who deliberately do so. . Article 194 of Act No 36 Of 2009 states that: "Every person who deliberately has an abortion that does not comply with the provisions referred to in Article 75 paragraph (2) shall be punished with imprisonment of up to 10 years and a maximum fine of IDR 1,000,000,000. , 00 (one billion rupiah)".

\section{Closing}

Liability to criminal law against perpetrators of abortion in Indonesia based on the Criminal Code is regulated in Book Two of Chapter XIV on Crimes of Decency, in particular Article 299, and Chapter XIX, Articles 346-Articles 349 which are classified as crimes against life. The prohibition on abortion in the Criminal Code is contained in Article 299, Article 346, Article 347, Article 348, and Article 349, which have explicitly regulated the prohibition of having an abortion for any reason, including abortion for reasons of emergency (forced), namely as a result of rape, both prohibitions against the perpetrator or the one who helps with the abortion. Even medical professionals will get double the penalty for helping to have an abortion. The provisions for regulating abortion in Act No 36 of 2009 are set out in Article 75, Article 76, Article 77, and Article 194. Although, the law prohibits the practice of abortion, but in certain circumstances it does. Abortion practices that are contrary to statutory regulations are regulated in Article 194 of Act No 36 of 2009, which can ensnare doctors and / or health workers who deliberately carry out illegal abortions or women who deliberately do so, with a maximum imprisonment. 10 years and a maximum fine of IDR 1,000,000,000.00 (one billion rupiah). 
The government needs to conduct socialization with a religious approach, especially to adolescents regarding the knowledge of the prohibition and dangers of having an abortion, and to explain that abortion is an illegal act with quite heavy sanctions.

\section{References}

\section{Journal:}

[1] Damayanti, Eka and Aryani Witasari, December 2019. Legal Protection from Provocate Abortion Againts the Child Conceived Because Rape (Case Study on Jurisdiction Ex Residency of Cirebon). Jurnal Daulat Hukum. Vol. 2 No. 4, Faculty of Law, Universitas Islam Sultan Agung, Semarang.

\section{Books:}

[1] Arsyad, Jawade Hafidz and Dian Karisma. (2018). Sentralisasi Birokrasi Pengadaan Barang \& Jasa Pemerintah. Cetakan Pertama. Jakarta: Sinar Grafika.

[2] Asmarawati, Tina. (2013). Hukum \& Abortus. Edisi Pertama. Cetakan Kesatu. Yogyakarta: Dee-publish.

[3] Fajar ND, Mukti and Yulianto Achmad. (2010). Dualisme Penelitian Hukum Normatif dan Empiris. Yogyakarta: Pustaka Pelajar.

[4] Fauziyah, Yulia and Cecep Triwibowo. (2013). Medical Book, Bioteknologi Kesehatan Dalam Perspektif Etika dan Hukum. Cetakan Pertama. Yogyakarta: Nuha Medika.

[5] Martha, Aroma Elmina and Singgih Sulaksana. (2019). Legalisasi Aborsi. Cetakan Pertama. Yogyakarta: UII Press.

[6] Maskawati, Andriani Misdar, and Muji Iswanty. (2018). Hukum Kesehatan, Dimensi Etis dan Yuridis Tanggung Jawab Pelayanan Kesehatan. Yogyakarta: Litera.

[7] Muchtar, Masrudi. (2015). Bidan dan Dinamika Hukum Kesehatan Reproduksi di Indonesia. Cetakan Kedua. Sleman: Aswaja.

[8] Notoatmodjo, Soekidjo. (2010). Etika \& Hukum Kesehatan. Cetakan Pertama. Jakarta: Rineka Cipta.

[9] Praja, Juhaya S. (2011). Teori Hukum dan Aplikasinya. Cetakan Pertama. Bandung: Pustaka Setia.

[10] Sadi Is, Muhamad. (2017). Etika Hukum Kesehatan, Teori dan Aplikasinya Di Indo-nesia, Cetakan Kedua. Jakarta: Kencana Prenada Media.

[11] Seran, Marcel and Anna Maria Wahyu Setyowati. (2010). Dilema Etika dan Hukum Dalam Pelayanan Medis. Cetakan Kesatu. Bandung: Mandar Maju.

[12] Soeratno and Lincolin Arsyad. (2003). Metodologi Penelitian Untuk Ekonomi Dan Bisnis. Yogyakarta: UPP AMP YKPN.

[13] Soge, Paulinus. (2015). Hukum Aborsi Tinjauan Politik Hukum Pidana Terhadap Perkembangan Hukum Aborsi di Indonesia. Cetakan Ketiga. Yogyakarta: Universitas Atma Jaya Yogyakarta. 
[14] Sudarmanto. (2018). Kinerja dan Pengembangan Kompetensi SDM, Teori, Dimensi Pengukuran, dan Implementasi Dalam Organisasi. Cetakan Keempat. Yogyakarta: Pustaka Pelajar.

[15] Suharto and Junaidi Efendi. (2010). Panduan Praktis Bila Menghadapi Perkara Pidana, Mulai Proses Penyelidikan Sampai Persidangan. Jakarta: Prestasi Pustaka.

[16] Susanti, Dyah Ochtorina and A'an Efendi. (2018). Penelitian Hukum (Legal Research). Jakarta: Sinar Garfika.

[17] Warassih, Esmi. (2010). Pranata Hukum, Sebuah Telaah Sosiologis. Cetakan Kedua. Semarang: Badan Penerbit Universitas Diponegoro.

[18] Yunanto, Ari and Helmi. (2010). Hukum Pidana Malpraktik Medik, Tinjauan dan Perspektif Medikolegal. Edisi Pertama. Yogyakarta: ANDI. 